\title{
SCIENTIFIC / EDUCATIONAL COMMUNICATION AND LEADERSHIP ARWU VERSUS MOSIUR
}

\author{
COMUNICAÇÃO E LIDERANÇA CIENTÍFICA / EDUCACIONAL ARWU VERSUS \\ MOSIUR
}

\author{
COMUNICACIÓN Y LIDERAZGO CIENTÍFICO / EDUCATIVO ARWU VERSUS \\ MOSIUR
}

\author{
Riyaz Gataullovoch MINZARIPOV ${ }^{1}$ \\ Anastasia Viktorovna FAKHRUTDINOVA ${ }^{2}$ \\ Nataliia Nikolaevna ABAKUMOVA ${ }^{3}$ \\ Sisi $\mathrm{XU}^{4}$ \\ Irina Vasilyevna TERENTYEV 5
}

\begin{abstract}
The problem of promoting universities in international rankings, the ratio of the number of universities in China and the Russian Federation, as well as the selection of mechanisms for the successful promotion of universities in the Academic Ranking of World Universities (ARWU) and the Moscow international rating "Three University Missions" (MosIUR) are in the focus of research. The hypothesis is that the development of an international rating is a state task that meets the current conditions of globalization in the world. The results of ARWU and MosIUR universities in Russia and China for 2017-2019 are presented, a comparative analysis of the total number of Russian and Chinese universities, the dynamics of their progress in rankings is made. The results of a survey of university teachers about their level of awareness on ARWU and MosIUR are discussed. The conclusions about the orientation of universities in Russia and China towards the internationalization of the national system of higher education are drawn. The participation of Russian and Chinese universities in ARWU and MosIUR is an important state task in the context of world competitiveness of universities.
\end{abstract}

KEYWORDS: International rankings. Universities. ARWU. MosIUR. Internationalization.

RESUMO: O problema da promoção de universidades no ranking internacional, a relação do número de universidades na China e na Federação Russa, bem como a seleção de mecanismos para a promoção bem-sucedida de universidades no Ranking Acadêmico de

\footnotetext{
${ }^{1}$ Kazan Federal University (KPFU), Kazan - Russia. Vice Director. E-mail: riaz.minzaripov@kpfu.ru

${ }^{2}$ Kazan Federal University (KPFU), Kazan - Russia. Professor of the Department of Foreign Languages, Institute of International Relatons. ORCID: https://orcid.org/0000-0001-7872-7507. E-mail: avfach@mail.ru

${ }^{3}$ National Research Tomsk State University (TSU), Tomsk - Russia. Associate Professor of the Department of General and Pedagogy Psychology. PhD in Education. ORCID: https://orcid.org/0000-0003-3221-0400. E-mail: niv tomsk@mail.ru

${ }^{4}$ East China Normal University (ECNU), Shanghai - China. Professor of the International Chinese Language and Culture Institute. ORCID: https://orcid.org/0000-0003-0882-1412. E-mail: 306010184@qq.com

${ }^{5}$ Kazan Federal University (KPFU), Kazan - Russia. Professor of the Department of International Relations, World Politics and Diplomacy, Institute of International Relations. Doctor of Sciences (Pedagogics). ORCID: https://orcid.org/0000-0002-7072-6822.E-mail: iterenteva49@mail.ru
} 
Universidades Mundiais (ARWU) e a classificação internacional de Moscou "Três Missões Universitárias" (MosIUR) estão no foco da pesquisa. A hipótese é que o desenvolvimento de uma classificação internacional é uma tarefa estatal que atende às condições atuais da globalização no mundo. São apresentados os resultados das universidades ARWU e MosIUR na Rússia e na China para 2017 - 2019, uma análise comparativa do número total de universidades russas e chinesas, a dinâmica de seu progresso na classificação é feita. São discutidos os resultados de uma pesquisa com professores universitários sobre seu nível de conscientização sobre o ARWU e MosIUR. As conclusões sobre a orientação das universidades, na Rússia e na China, para a internacionalização do sistema nacional de ensino superior são tiradas. A participação das universidades russas e chinesas no ARWU e MosIUR é uma importante tarefa estatal no contexto da competitividade mundial das universidades.

PALAVRAS-CHAVE: Rankings internacionais. Universidades. ARWU. MosIUR. Internacionalização.

RESUMEN: El problema de la promoción de universidades en los rankings internacionales, la proporción del número de universidades en China y la Federación de Rusia, así como la selección de mecanismos para la promoción exitosa de universidades en el Ranking Académico de Universidades del Mundo (ARWU) y el Internacional de Moscú. calificación "Tres misiones universitarias" (MosIUR) están en el foco de la investigación. La hipótesis es que el desarrollo de una calificación internacional es una tarea estatal que cumple con las condiciones actuales de globalización en el mundo. Se presentan los resultados de las universidades ARWU y MosIUR en Rusia y China para 2017 - 2019, se realiza un análisis comparativo del número total de universidades rusas y chinas, se realiza la dinámica de su progreso en los rankings. Se discuten los resultados de una encuesta a profesores universitarios sobre su nivel de conocimiento sobre ARWU y MosIUR. Se extraen las conclusiones sobre la orientación de las universidades de Rusia y China hacia la internacionalización del sistema nacional de educación superior. La participación de universidades rusas y chinas en ARWU y MosIUR es una tarea estatal importante en el contexto de la competitividad mundial de las universidades.

PALABRAS CLAVE: Rankings internacionales. Universidades. ARWU. MosIUR. Internacionalización.

\section{Introduction}

The international process of globalization exert its influence not only on the economies and policy of countries, but also makes significant adjustments to the activities of universities. First of all, this is connected with the attraction of foreign educational institutions, academic mobility system, the possibility of getting $\mathrm{PhD}$ degree from another country, developing of joint educational programs and leads to the opening of foreign language centers. The state is interested in the development of education, as well as in the participation of its universities in the global educational market and their promotion to 
leadership positions. An adequate and valid mechanism that can provide an assessment of the activities of universities is ranking. QS World University Rankings, Webometrics, Times Higher Education World University Rankings, is a small part of the ranking systems, that are in demand, verified and valuable among educational, scientific and professional communities (MUSSARD; JAMES, 2018; ABAKUMOVA; XU, 2020). Getting into these ranking is considered prestigious for any educational institution. This position has been formed over many years of practice in ranking universities, since up to half of the indicators in different ratings use data based on reputation surveys (MUSSARD; JAMES, 2018; SITNICKI, 2018).

The results of the Academic Ranking of World Universities (MESTER, 2017). and the Moscow international rating "Three University Missions" (LANDINEZ; KLIEWE; DIRIBA, 2019). the development of which was initiated by Russia, are of the interest of our study. The Academic Ranking of World Universities (Shanghai Ranking) was first published in 2003, its main goal, at that time, was to determine the gap between Chinese universities and worldclass universities in terms of academic science and research activities. Russia began to develop its own international rating after thirteen years. The start of development was officially announced on November 2, 2016. The Russian Union of Rectors and the Russian Academy of Sciences initiated the development of the Moscow international rating "Three University Missions". The main goal of this rating was to adequately assess: 1) the real quality of knowledge of graduates, 2) the introduction of advanced teaching methods and 3) the characteristics of national pedagogical and scientific schools.

The analysis of the literature, regulatory documents and statistical databases showed that the fundamental difference between the Shanghai and Moscow ranking systems is the calculation of indicators based on the reputation ranking (ARWU) or quantitative indicators that are uniformly measured in the areas of "Education", "Science" and "University and Society" (MosIUR). Otherwise, the prerequisites and the need to develop ranking technology are similar. The Ministry of Education of China is implementing various projects and programs aimed at promoting Chinese universities in the international educational market. Currently, the National Medium and Long-Term Reform and Development Program for Education for 2010-2020 is being implemented. Reform's and Development Program's aim was to reduce the difference between the developing group of Chinese universities and world's leading universities by 2020. Previously, there were projects - Project 211 (SUN et al., 2017) and Project 985 (LI, 2018), allele joined together and transformed into the new 
Double-First Class University Plan project ${ }^{6}$. the purpose of which is to create universities and world-class training areas.

In 2013, the President of the Russian Federation initiated the project "TOP 5 - 100", aimed at implementing competitive research programs by leading research universities ${ }^{7}$. Three years later, it was decided to develop the Moscow international ranking "Three University Missions".

\section{Methods}

Theoretical methods were implemented in the work - literature review, normative documents analysis, statistical databases in the field of ranking universities study, phenomenological and paradigmatic methods (FAKHRUTDINOVA; SHAMSUTDINOVA; RAMSIYA, 2019). Empirical research methods: a survey, a comparative analysis of the ranking data of the Academic Ranking of World Universities (MESTER, 2017). and the Moscow International University Ranking "Three University Missions" (LANDINEZ; KLIEWE; DIRIBA, 2019). for the period from 2017 to 2019. Between 2017 and 2019 A survey of teachers from Kazan Federal University, National Research Tomsk State University and East China Normal University was conducted; the total number of respondents - 718 people.

\section{Results and Discussion}

A comparative analysis of the results of the Academic Ranking of World Universities and the Moscow international ranking of universities "Three University Missions" for the period of 2017 - 2019 between universities in Russia and China has been carried out. The results are presented in Table 1 and Table 2.

Table 1 - Results of the Academic Ranking of World Universities of the Universities of Russia and China (2017 - 2019) according to the website ${ }^{8}$ (MESTER, 2017)

\begin{tabular}{|l|l|l|l|l|l|l|}
\hline Country/year & \multicolumn{2}{l|}{ Russia } & \multicolumn{3}{l|}{} \\
\cline { 2 - 8 } Group & 2017 & 2018 & 2019 & 2017 & 2018 & 2019 \\
\hline Highest rank & 48 & 45 & 43 & 93 & 86 & 87 \\
\hline $1-100$ & 2 & 3 & 4 & 1 & 1 & 1 \\
\hline $101-150$ & 4 & 4 & 4 & & & \\
\hline
\end{tabular}

${ }^{6}$ Available: www.stats.gov.cn/english/Statisticaldata. Access: 10 dec. 2020.

${ }^{7}$ Available: https://base.garant.ru/70336756/. Access: 10 dec. 2020.

${ }^{8}$ Available: www.shanghairanking.com. Access: 10 dec. 2020.

RPGE- Revista on line de Política e Gestão Educacional, Araraquara, v. 25, n. esp. 1, p. 557-566, mar. $2021 . \quad$ e-ISSN:1519-9029 DOI: https://doi.org/10.22633/rpge.v25iesp.1.14996 


\begin{tabular}{|l|l|l|l|l|l|l|}
\hline $151-200$ & 3 & 5 & 9 & & & \\
\hline $201-300$ & 9 & 11 & 10 & & & \\
\hline $301-400$ & 15 & 12 & 12 & 1 & 1 & 1 \\
\hline $401-500$ & 12 & 17 & 19 & 1 & 2 & 2 \\
\hline $501-600$ & 13 & 11 & 14 & 1 & & \\
\hline $601-700$ & 21 & 17 & 18 & & & 1 \\
\hline $701-800$ & 10 & 17 & 16 & & 2 & 1 \\
\hline $801-900$ & - & 14 & 14 & & 3 & 4 \\
\hline $901-1000$ & - & 13 & 12 & & 3 & 1 \\
\hline
\end{tabular}

Source: Prepared by the authors

Based on the results presented in the table, we can point to the stable position of Chinese universities. The highest position in the ARWU ranking is occupied by Tsinghua University, the second highest place - by Beijing University (57 in 2018 and 53rd in 2019). Beijing University has been the leader in the MosIUR ranking for all three years (Table 2). It demonstrates positive dynamics in growth from 33 position in 2017 to 16 position in 2019 . This not only indicates the stability of measured quantitative indicators, but also growth, both in attitude to the university itself and it's position in comparison with other universities.

Until 2017, only Moscow State University was included in the ARWU rating. Today, Moscow State University holds the highest position among Russian universities (93rd place in 2017, 86th place in 2018 and 87th place in 2019). Judging by the results of three years, for Russian universities there is a real difficulty not only in entry, but also in promotion in the ranking. It is noteworthy that in addition to Moscow State University and St. Petersburg State University, the ARWU ranking included universities - participants in the TOP-5 - 100 project. The most successful of Russian universities presented ARWU in 2018. It included 12 Russian universities: in the group 301 - 400 Saint Petersburg State University; in group 401 - 500 Moscow Institute of Physics and Technology and Novosibirsk State University. Tomsk State University and Ural Federal University were included in the group 701 - 800. The largest groups are 801 - 900 (ITMO University, Kazan (Volga region) Federal University, The National University of Science and Technology MISiS) and groups 901 - 1000 (National Research University Higher School of Economics, Peter the Great St. Petersburg Polytechnic University, Tomsk Polytechnic University).

According to the results of 2019, the Moscow Institute of Physics and Technology and Novosibirsk State University were included in the 401-500 group (as well as in 2018); group 601 - 700 - National Research Nuclear University MEPhI; Ural Federal University is included in group 701-800. The largest group 801 - 900: ITMO University, Kazan (Volga region) Federal University, The National University of Science and Technology MISiS and Tomsk 
State University. The National Rating University is closed by the National Research University Higher School of Economics, which entered the group 901 - 1000. Failed to stay in the 2019 ranking Peter the Great St. Petersburg Polytechnic University and Tomsk Polytechnic University. We can assume that the targeted efforts of the educational institutions for their competitiveness rise through improvement of educational and research policy receives an adequate assessment in the form of ranking results.

Table 2 - The Results of the Moscow International Rating "Three University Missions" of Universities in Russia and China (2017 - 2019) According to the website 9 (LANDINEZ; KLIEWE; DIRIBA, 2019)

\begin{tabular}{|l|l|l|l|l|l|l|}
\hline \multirow{2}{*}{$\begin{array}{l}\text { Country/year } \\
\text { Group }\end{array}$} & \multicolumn{2}{l}{ China } & \multicolumn{2}{l|}{ Russia } \\
\cline { 2 - 8 } & 2017 & 2018 & 2019 & 2017 & 2018 & 2019 \\
\hline Highest rank & 33 & 25 & 16 & 25 & 23 & 22 \\
\hline $1-100$ & 3 & 6 & 6 & 3 & 3 & 3 \\
\hline $101-150$ & 4 & 1 & - & 4 & 1 & 2 \\
\hline $151-200$ & 3 & 1 & 4 & 6 & 3 & - \\
\hline $201-300$ & - & 5 & 8 & - & 9 & 6 \\
\hline $301-400$ & - & - & 14 & - & 1 & 4 \\
\hline $401-500$ & - & - & 8 & - & - & 2 \\
\hline $501-600$ & - & - & 8 & - & - & 2 \\
\hline $601-700$ & - & - & 19 & - & - & 4 \\
\hline $701-800$ & - & - & 21 & - & - & 8 \\
\hline $801-900$ & - & - & 14 & - & - & 7 \\
\hline $901-1000$ & - & - & 9 & - & - & 8 \\
\hline $1001-1100$ & - & - & 7 & - & - & 10 \\
\hline $1101-1200$ & - & - & 6 & - & - & 16 \\
\hline
\end{tabular}

Source: Prepared by the authors

The first year of MosIUR had ranking groups of 200 universities; in the next two years, the sample size increased to 1,200 in 2019. The total number of Chinese universities included in MosIUR is steadily increasing, from 10 in the first year, to 13 in the second and 124 universities in 2019. In comparison, there were 72 Russian universities in 2019. A third of these universities are in the 1001 - 1200 rank group. They can, on the one hand, be defined as universities that have a certain potential and will grow in ranking indicators, however, with increasing competition for a place in the ranking, these universities may not be included into the ranking for the next year.

The highest positions in MosIUR among Chinese universities are occupied by Beijing University (33rd place in 2017, 25th place in 2018 and 16th place in 2019). Tsinghua University in 2018 received the 36th rank, despite the fact that in the Shanghai ranking it

${ }^{9}$ Available: https://mosiur.org/. Access: 10 dec. 2020.

RPGE- Revista on line de Política e Gestão Educacional, Araraquara, v. 25, n. esp. 1, p. 557-566, mar. $2021 . \quad$ e-ISSN:1519-9029 
consistently ranks first among Chinese universities. In Russian universities, the three leaders have been determined since 2017 - Moscow State University, St. Petersburg State University and MIPT. The most significant growth in terms of indicators is demonstrated by St. Petersburg State University (in 2017 - 72 ranks, in 2018 - 61 ranks and in 2019 - 41 ranks). Since 2017 , the leading research universities of the TOP 5-100 project also occupy certain positions in MosIUR, for example, National Research University Higher School of Economics - 107th position in 2017, 122th position in 2018 and 121th position in 2019; National Research Nuclear University MEPhI - 131st position in 2017, 154th place in 2018 and 147th place in 2019; Novosibirsk National Research State University - 132th position in 2017 and 158th position in 2018; Tomsk Polytechnic University - 136th position in 2017 and 205th place in 2018. Russian universities, as shown by MosIUR's three-year results, do not demonstrate stability in terms of performance and ranking in the global group.

In order to assess the awareness of the university community about the new Moscow international ranking "Three University Missions”, a survey of teachers from Kazan Federal University, National Research Tomsk State University, East China Normal University was conducted in 2017 - 2019. For three years, teachers at East China Normal University (240 people) in a survey note their lack of awareness about Mos IUR. Answers to questions about ARWU are positive - they demonstrate their knowledge, indicate specific universities and ranks in the ranking in $100 \%$ of cases. Russian teachers (478 respondents) only in the last two years began to celebrate their awareness of MosIUR - 43 people (9\%) in 2018 and 61 people $(13 \%)$ in 2019. All 478 respondents are informed about the ARWU rating.

\section{Summary}

The development of the system of higher education in Russia is focused on internationalization (KHOVANSKAYA; FAKHRUTDINOVA; MAKLAKOVA, 2017). World rankings ARWU and MosIUR can be used as a tool for assessing the development of Russian and Chinese universities. In the long run, the ARWU results can help assess the internationalization of higher education. The promotion of Russian and Chinese universities in ARWU and MosIUR is a reflection of real state policy. Thus, the participation of universities in Russia and China in ARWU and MosIUR is an important state task of the global competitiveness of universities. Today, the interest of the Russian and Chinese governments in the development of their universities is obvious. Significant decisions have already been made - the creation of a national university ranking comparable to world 
analogues and the development of national platforms for scientific publications compatible with Web of Science. All this is reflected in the promotion of universities in world rankings, their number and the importance of the places taken. The recorded increase in the number of Russian and Chinese universities in the ARWU and MosIUR ratings is determined by changes in the conditions of international activity of universities in Russia and China.

\section{Conclusions}

Globalization issues are increasingly affect modern universities and force them to look for inadequate mechanisms to include and promote universities in international rankings. One of such mechanisms is the development of an international rating as a state task. The experience of China is indicative, for sixteen years of the Shanghai ranking system existence, which was developed as a mechanism for the comparative assessment of Chinese universities with the best world practices, and has finally received an international recognition, getting into ARWU is considered prestigious for the best world universities. Based on this positive experience, the Chinese government is consistently launching projects and programs aimed at increasing of the internationalization processes of education (attracting foreign teachers and students, implementing joint educational programs and opening foreign language centers). All this is reflected in the constant growth of indicators of Chinese universities in international rankings.

In the Russian practice of higher education, the initial task was to enter international rankings and advance to high positions, and, subsequently, the need to develop MosIUR was determined. Currently, the process of formation and testing of the rating methodology is an ongoing process. The unifying element is the role of the state as supporting in the promotion of universities in international rankings. In China and Russia, long-term projects and programs have been adopted and are being implemented that support the development of the international competitiveness of universities.

ACKNOWLEDGEMENTS: The work is performed according to the Russian Government Program of Competitive Growth of Kazan Federal University. 


\section{REFERENCES}

ABAKUMOVA, N. N.; XU, S. Entry and promotion of universities in the world rankings: the Russian and Chinese experience. 2020.

CHINA. Ministry of Education of China. 2010-2020 National medium- and long-term Education Reform and Development Program. Available:

http://www.moe.edu.cn/srcsite/A01/s7048/201007/t20100729_171904.html. Access: 10 dec. 2020.

CHINA. National Bureau of Statistics of China. Available:

http://www.stats.gov.cn/english/Statisticaldata/AnnualData/. Access: 10 dec. 2020.

FAKHRUTDINOVA A.V.; SHAMSUTDINOVA D.V.; RAMSIYA N.G, Paradigmatic methodology of civic culture formation process in young generation. Journal of Sociology and Social Anthropology, v.10, n. 4, p. 198-202, 2019.

KHOVANSKAYA, E. S.; FAKHRUTDINOVA, A. V.; MAKLAKOVA, N. V. University as a social phenomenon. Man in India, v. 97, n. 9, p. 101-107, 2017.

LANDINEZ, L.; KLIEWE, T.; DIRIBA, H. Entrepreneurial University Indicators in Global University Rankings. In: Developing Engaged and Entrepreneurial Universities. Springer, Singapore, 2019. p. 57-85.

LI, S. Transnational Higher Education in China: Thirty Years of Development. Higher Education Forum, v. 6, p. 49-58, 2018.

MESTER, G. Academic Ranking of World Universities. Review of the National Center for Digitization, Faculty of Mathematics, University of Belgrade, 2017. 50 p.

MUSSARD, M.; JAMES, A. P. Engineering the global university rankings: Gold standards, limitations and implications. IEEE Access, v. 6, p. 6765-6776, 2018.

RUSSIA. Decree of the Government of the Russian Federation of March 16, 2013 No. 211. On measures of state support for leading universities of the Russian Federation in order to increase their competitiveness among the world's leading scientific and educational centers. Available: https://base.garant.ru/70336756/. Access: 10 dec. 2020.

SITNICKI, M. W. determining the priorities of the development of Eu research universities Based on the analysis of rating indicators of World-class universities. Baltic Journal of European Studies, v. 8, n. 1, p. 76-100, 2018.

SUN, J. J. M. et al. Impact of English on education reforms in China: with reference to the learn-English movement, the internationalisation of universities and the English language requirement in college entrance examinations. Journal of Multilingual and Multicultural Development, v. 38, n. 3, p. 192-205, 2017. 


\section{How to reference this article}

MINZARIPOV, R. G.; FAKHRUTDINOVA, A. V.; ABAKUMOVA, N. N.; XU, S.; TERENTYEV, I. V. Scientific / Educational communication and leadership ARWU versus MosIUR. Revista on line de Política e Gestão Educacional, Araraquara, v. 25, n. esp. 1, p. 557-566, mar. 2021. e-ISSN:1519-9029. DOI: https://doi.org/10.22633/rpge.v25iesp.1.14996

Submitted: 06/11/2020

Required revisions: $18 / 01 / 2021$

Approved: $23 / 02 / 221$

Published: 01/03/2021 